\title{
WHAT HAPPENED TO COMET KOHOUTEK?
}

\author{
by G. N. PATTERSON*
}

The much publicized "Comet-ofe-Century" turned out to be a visual id. What happened to it? Was the st scientific observational program a iste of time?

What actually happened is, of urse, well known. It's the "Why?" at is yet unanswered. The comet ightened gradually as it approached sun, although not as brilliant as iginally forecast. It did achieve a illiance as bright as Venus when it is close in to the sun but only the KYLAB astronauts could see it at at time. Then, as it swung around the $\mathrm{n}$, the brilliance dropped sharply $d$ it was only visible to the naked e, provided you knew exactly where look for it, for less than a week. It adually faded in brightness until it uld only be seen with the aid of noculars or a telescope. The great eeping tail forecast never did velop. Why?

Any answer to this question is highly eculative at this time. The recasting of a comet's brightness is ways a calculated guess based on the rformance of previous comets and, nce, is a very unpredictable figure. much depends upon the contuents that form the nucleus of the met and these can only be known afthe comet has developed. In this inince, the final answer will only be own when all the observational data recovered and analyzed and that uld take up to a year or more.

What is known is that the nucleus of

hysics Department

iversity of Saskatchewan,

skatoon. Saskattchewan.
Comet Kohoutek was larger than any other known comet since scientific measurements have been taken. Earthbased spectroscopic measurements have been taken showing a wide variety of chemical constituents common to other comets, plus other constituents not noticed in previous comets: The full story will only be completed once the data from SKYLAB is recovered and analyzed.

It is presently being speculated that Comet Kohoutek is a new kind of comet. The vast amount of data being obtained will result in a very intensive re-appraisal of our present concept of comets and, because of this, Comet Kohoutek can still justifiably be labelled "The Comet of the Century", even though it resulted in a very poor visual display.

\section{Ill 其parg Agu}

Those who knew the Blue Jay thirty years ago will remember the stiff yellow cover with the blue lettering, on which appeared the names of the officers of the Yorkton Natural History Society and a statement of the Society's objects. The stated aim of the Society was simply expressed, but comprehensive: "To foster an active interest in every branch of nature study, and to promote the conservation of all wild life; also to act as a connecting link between nature lovers in Saskatchewan." 
By the time five numbers of the Blue Jay had appeared, members were beginning to express an interest in how it was published. Some members, who realized that the Society had incurred a deficit in the previous year because of the cost of publication, were able to send donations. In order to reply to those who asked how the Blue Jay was actually produced, Mrs. Priestly wrote in the Jan.-Feb.-Mar. 1944 issue:

here briefly is the "set-up."

Mrs. Priestly is editor and responsible for the whole job of writing it. Stuart Houston is printer and publisher. Mr. Priestly comes into the picture as copy-reader. The "blueing" of the title letters on the front page is done by a "bee" of as many Yorkton members as can be persuaded to revert to childhood and spend an afternoon or evening crayoning. Putting the pages together and rolling the bulletin for mailing is carried out by the boys in our society - Vernon Barnes, Neil Black, Harvey Beck, Jim Smith and Michael Priestly, to whom special thanks are due. And, needless to say, no "Blue Jay" could be produced without the many interesting letters from members from all over the province, as well as suggestions received from Yorkton friends.

\section{NATIONAL WILDLIFE WEEK April 8-13, 1974}

The theme of National Wildlife Week this year is "Preservation of Wetland Habitat". More than 100 years ago, Henry David Thoreau wrote: "Hope and the future for me are not in lawns and cultivated fields, not in towns and cities, but in the impervious and quaking swamps ... A town is saved, not more by the righteous men in it than by the woods and swamps that surround it." If you share Thoreau's feelings, then let your elected officials - city, municipal, provincial and federal - know how you feel about the environmental problem of wetland destruction. Write, phone or see them in person. (Partly from Canadian Wildlife Federation's Wildlife News, Autumn, 1973).

\section{SNHS FIELD CAMPS}

Grasslands camp near Val Marie in the heart of the ranching couritry, May 25-27. For persons interested in studying or photographing native grassland and the associated flora and fauna, including prairie dogs in the Society's Prairie Dog Sanctuary.

Migration camp at the north end of
Last Mountain Lake during the San hill Crane migration, August 31 September 2.

Fee of $\$ 40.00$ per person. Ea camp is limited to 20 persons, with places in each reserved for outprovince registrations.

For more information -

Mrs. Jeanie Wagner,

SNHS Secretary,

University of Sask., Regina Camp

Regina, Saskatchewan.

\section{SUMMER MEET AT ESTEVAI}

Our 1974 Summer Meeting will headquartered at Estevan. Tom Ge tles is organizing a series of field tri to explore this unique area and Llo Peterson is working with local mei bers to plan other program items. $\mathrm{Pl}$ to be with us on June 7-8-9.

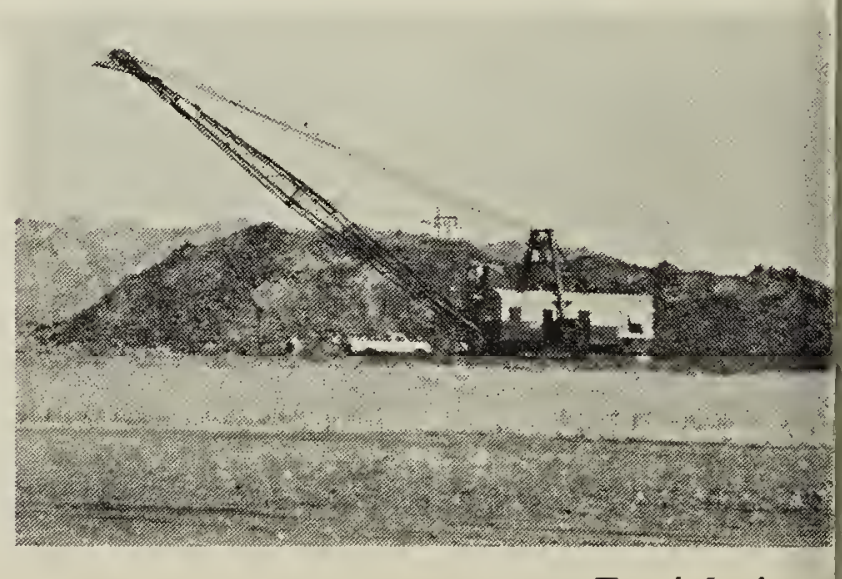

Fred Lahrm

Dragline at strip-mining operations $n$ Estevan, Saskatchewan. 